\title{
Description of the second species of the genus Taiwanophodes Hlaváč, 2002 (Coleoptera: Staphylinidae: Pselaphinae) from Vietnam
}

\author{
Описание второго вида рода Taiwanophodes Hlaváč, 2002 \\ (Coleoptera: Staphylinidae: Pselaphinae) из Вьетнама
}

\author{
Rostislav Bekchiev \\ Ростислав Бекчиев
}

\begin{abstract}
National Museum of Natural History, 1 Tsar Osvoboditel Blvd., 1000 Sofia, Bulgaria. E-mail: rbekchiev@gmail.com Национальный музей естественной истории, бул. Царя Освободителя 1, 1000 София, Болгария.
\end{abstract}

KEY WORDS. Pselaphinae, Tyrini, Taiwanophodes, new species, taxonomy, Vietnam.

КЛЮЧЕВЫЕ СЛОВА. Pselaphinae, Tyrini, Taiwanophodes, новый вид, таксономия, Вьетнам.

ABSTRACT. Second species of the genus Taiwanophodes - T. magnus sp.n. from Vietnam is described and illustrated.

РЕЗЮМЕ. Приводится описание второго вида рода Taiwanophodes - T. magnus sp.n. из Вьетнама с иллюстрациями.

\section{Introduction}

The genus Taiwanophodes was erected by Hlaváč [2002] to accommodate a single species from Taiwan. According to the description, the genus is distinguished from the others genera of the tribe Tyrini by the following combination of characters: second tarsal segment broadly lobed beneath the third and extended nearly to tarsal claws; head with well-defined frontal and vertexal fovea; maxillary palpi with segments III-IV asymmetric, broadly expanded externally; pronotal lateral and median fovea well-defined and connected by evanescence antebasal sulcus. In the paper [Hlaváč, 2002] describing the first species of the genus - Taiwanophodes minor Hlaváč, 2002, the author also mentioned the existence of a second species of the genus from Vietnam, but the lack of material (only one female) made impossible its description. The examination of the collection of Dr. Sergey Kurbatov (Moscow) gave me the opportunity to find more specimens of most probably of this species. In the present work a detailed description of this species is given.

\section{Materials and methods}

Dissections were made using standard techniques, genitalia and small parts were mounted in Euparal or Canada balsam on an acetate labels which are pinned with the specimens. All photos were done by microscope Olimpus SZ-61 with camera Olympus Color- view I. The width of head is measured through eyes.

The material used for this study is deposited in the following collections:

NMNH - National Museum of Natural History, Sofia, Bulgaria;

ZMUM - Zoological Museum of Moscow State University, Moscow, Russia;

PCSK - S. Kurbatov private collection, Moscow, Russia.

\section{Species description}

Taiwanophodes magnus Bekchiev sp.n. Figs $1-8$

MATERIAL. Holotype: $10^{7}-\mathrm{N}$ Vietnam, $180 \mathrm{~km}$ SSW Hanoi, 40 km SW Thanh Hóa, Ben En Nat. Park, 24.08.97, 50 m, UV light, leg. Napolov (ZMUM); Paratypes: $30^{7} 0^{7}-$ same data as holotype; 107, 2 우 (label in Russian) - N Vietnam,Thanh Hóa Province, Lang Chang, 24.01.1989, leg B. Korotyaev (NMNH, PCSK).

DESCRIPTION. Body length: male $-3.00-3.22 \mathrm{~mm}$, female $-2.75-2.84 \mathrm{~mm}$ (Fig. 1), redish-brown. Head (0.57$0.59 / 0.60-0.62 \mathrm{~mm}$ ) with bilobed front, frontal sulcus deep, almost reaching middle of head. Frontal and vertexal fovea deep and setose. Genae forming two highly granulated carinae below eyes. Eyes big and prominent. Pubescence of head dense and long, especially in temples.

Antennae with scape about 2.5 times as long as wide; pedicel, antennomeres III-VI subequal; VII -VIII as long as wide; IX big, triangular; $\mathrm{X}$-IX with strong modification as in Figs 2-3. Maxillary palpi typical for the genus. Pronotum $(0.59 / 0.62 \mathrm{~mm})$ rounded, lateral humps relatively small, median hump big and prominent. Pubescence dense, clear and short. Elytra $(0.88 / 1.13 \mathrm{~mm})$ almost quadrate, humeri well pronounced, largest part situated in the second third of elytra, strongly convex in middle, just before largest part, covered with short and clear pubescence. Metaventrite with two hornlike processes, bifurcated at apex. Legs long and slender. Profemora with very small triangular protuberance (Fig. 5) in male, and with strong protuberance in the female (Fig. 4). Protibiae strongly modified (Fig. 6) with deep internal indentation, limited in apical internal part with triangular protuber- 


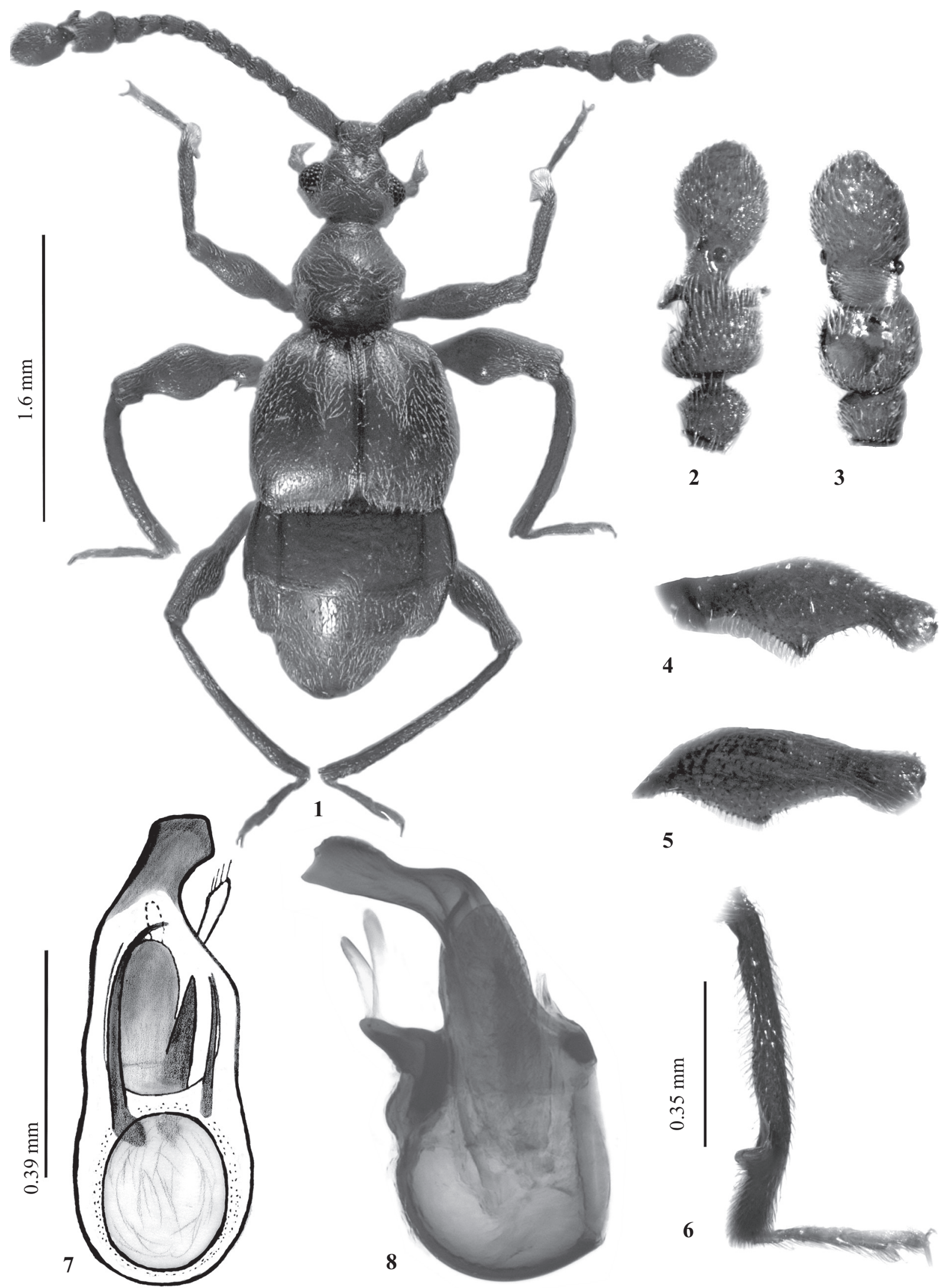

Figs 1-8. T. magnus sp.n; 1 - habitus; $2-3$ - antennal club; 4-5 - profemura; 6 - protibia; 7-8 - aedeagus; 1-3, 5-8 - male, holotype; 4 - female, paratype; 2,8 - lateral view; 3 - ventral view; 7 - dorsal view.

Рис. 1-8. T. magnus sp.n; 1 - габитус; 2-3 - булава усика; 4-5 - переднее бедро; 6 - передняя голень; 7-8 - эдеагус; 1-3, 5-8 - самец, голотип; 4 - самка, паратип; 2,8 - сбоку; 3 - снизу; 7 - сверху. 
ance; pubescence long and fine. Mesotrochanters with one spine, situated in distal internal part. Mesofemora inerme. Mesotibiae with strong apical spur. Metacoxae with short triangular dent. Metatrochanters, femora and tibiae inermes. Abdomen with large first visible tergite, about 2.5 times as long as second one. Strongly convex in posterior middle part and covered with short and clear pubescence. Abdominal segment IX with shallow incision in the middle. Aedeagus about $0.79 \mathrm{~mm}$ long, as in Figs 7-8.

SEXUAL DIMORPHISM. Female with unmodified, simple antennae; antennomere $\mathrm{X}$ about 2.3 times as long as wide. Protrochanters with one spine situated on the distal part Metaventrite without hornes. Abdominal tergite VIII and abdominal sternite IX with short protuberance.

DIFFERENTIAL DIAGNOSIS. The Taiwanophodes magnus sp.n. is closely related to Taiwanophodes minor from which differs by: 1) larger size; 2) shape of the antennae, pronotum and metasternal hornes; 3 ) very specific aedeagus.

ACKNOWLEDGEMENTS: This report was supported by project \# BG051PO001-3.3.04/41. I wish to thank Dr. Sergey Kurbatov (Russia) for his kindness and the opportunity to examine his collection, and Peter Hlaváč (Slovakia) for his critical reading and comments on the manuscript.

\section{References}

Hlaváč P. 2002. A Taxonomic Revision of Tyrini of the Oriental Region. II. Systematic study on the genus Pselaphodes (Coleoptera: Staphylinidae: Pselaphinae) and its allied genera // Annales de la Société entomologique de France. Vol.38. No.3. P.283-297. 